This chapter describes the educational possible selves of low-income mothers as they make the transition from welfare to work.

\title{
Reaching for the Future: The Education-Focused Possible Selves of Low-Income Mothers
}

\author{
Shawna J. Lee, Daphna Oyserman
}

More individuals than ever before are pursuing higher education to prepare themselves for a competitive labor market. This may mean returning to the classroom to attain a general equivalency diploma (GED) degree, or going on to technical college, community college, or a four-year university to attain job training and skills. Studies show that those who attain a GED have higher earnings than high school dropouts (Boesel, Alsalam, and Smith, 1998), and data are strongly supportive of the link between increased education at all levels and higher earnings. For example, in 2004, the median weekly earnings for full-time female workers with an associate degree was $\$ 608$, compared to $\$ 488$ for women with only a high school diploma (U.S. Bureau of the Census, 2005). As a result, an increasing number of nontraditional students are returning to the classroom. Based on the National Households Education Survey of 2001, participation in adult education increased from 40 percent in 1995 to 46 percent in 2001, with more women than men seeking adult education (Kim, Hagedorn, Williamson, and Chapman, 2004). This increase in nontraditional students suggests that individuals are pursuing their educational and employment goals well into adulthood, perhaps with the desire to use education as a means to achieve employment and financial gains.

While this is a promising trend, some segments of society may still be left behind. In this chapter we focus on low-income mothers who are making 
the transition from welfare to work. These mothers often have low levels of education and few job skills (Danziger, Ananat, and Browning, 2000). The jobs they are able to find tend to be concentrated in low-wage occupations (Lee, 2004; Loprest, 1999), and even with years of work experience, many former welfare recipients do not attain jobs with wages above the official U.S. poverty level (Danziger and Johnson, 2005; Loprest and Zedlewski, 2006). Low-income mothers in the transition from welfare to work face barriers that may deter their educational pursuits; the demands of caregiving and employment leave little time for education, and attaining an education is expressly not a goal of the welfare system. Yet education is central to job mobility. Studies show that job retention is difficult for women moving out of welfare in part because of lack of education, little past work experience, and deficits in soft skills such as work attitudes (Holzer and Wissoker, 2001; Loprest and Zedlewski, 2006). Facilitating the pursuit of educational goals may be one way to improve long-term outcomes for current and former welfare recipients who are moving to the workforce.

\section{Possible Selves and How They Are Related to Behavior}

Possible selves are the future-oriented aspect of identity, or the selves that one expects to become as well as the selves one wishes to avoid becoming (Markus and Nurius, 1986). Possible selves may be rooted in past successes and failures, and they also provide a way to make sense of one's current situation (Cross and Markus, 1991). For example, thinking about a future possible self of attending college is one way to understand behaviors enacted in the present that are related to that goal, such as studying hard and attending class. Possible selves can also facilitate identity exploration; that is, they are one way to try on new ideas about who you are and who you will become (Dunkel and Anthis, 2001). Among adults, new possible selves may emerge from a change in life phase or social context (Frazier and Hooker, 2006). For example, the life transition of becoming a parent increases the salience of parenting-focused possible selves (Hooker and others, 1996). Similarly, changes in welfare policy forcing transition to work result in greater salience of breadwinner possible selves among women who might otherwise focus primarily on parenting and family-focused possible selves (Lee and Oyserman, 2006).

In addition to representing positive images of the self one expects to become, possible selves include concerns for the future and the self-images one fears or wishes to avoid becoming. Feared possible selves in the academic domain may include wishing to avoid failing out of school or getting bad grades (Oyserman, Bybee, and Terry, 2006). Balance in possible selves-that is, when feared possible selves are paired with positive expected possible selves-is known to have important motivational consequences (Oyserman, Bybee, and Terry, 2006; Oyserman, Bybee, Terry, and Hart-Johnson, 2004). 
Balanced possible selves promotes attainment because linking a positive expected self to a feared self in the same domain pinpoints motivation to both work toward a positive future goal and to anticipate and strategize how to get around problems that may result in ending as a failure in that domain (one's feared possible self) (Oyserman, Bybee, Terry, and HartJohnson, 2004). The need for balance may be especially significant in low-income contexts because it is important to anticipate and plan for setbacks when barriers to education attainment are more likely to be present. It is not enough to expect to do well; one also has to be worried about doing badly.

Possible selves can create the link between hopes and dreams and current action by connecting behaviors with future desired selves (Cross and Markus, 1991; Lee and Oyserman, 2006; Oyserman and Markus, 1990). Seeing how behaviors are linked with distal goals like having a career can be difficult. To address this difficulty, it is necessary to feel that the distal possible self of a career is linked with more proximal possible selves like joining an adult education program. The act of connecting distal and proximal goals increases the importance of engaging in behaviors such as signing up for classes, attending class, and doing homework. This link between distal and proximal possible selves provides the pathway between the present and future goals. Intervention may facilitate efforts to link possible selves and current action. For example, the School-to-Jobs program successfully connected possible selves to current action, and students consequently demonstrated improved grades, reduced absences, improved in-class behavior, and fewer depressive symptoms at two-year follow-up (Oyserman, Bybee, and Terry, 2006; Oyserman, Terry, and Bybee, 2002).

\section{The Educational Goals of Adult Women}

Research linking possible selves to education has primarily been conducted with adolescents. These studies point out that education is important to low-income minority youth, despite a gap between desired possible selves (for example, going to college, becoming a doctor) and current educational attainment (Oyserman and Fryberg, 2006; Yowell, 2002). Yet to date, little is known about the educational possible selves of low-income mothers. A basic supposition of possible selves theory is that the array of possible selves one has at a particular time shapes what is believed to be possible for the future (Oyserman, forthcoming). Research demonstrates that family- and parenting-focused possible selves are important to women (Hooker and others, 1996; Lee and Oyserman, 2006); it is not known whether women focusing on the need to enter the workforce envision education-related possible selves as a part of that process. Moreover, it is not clear whether educational goals fit with other important possible selves related to parenting and employment (Kerpelman, Shoffner, and Ross-Griffin, 2002). 


\section{Examining the Education-Focused Possible Selves of Low-Income Mothers}

To address these questions, we examine the education-focused possible selves of two groups of low-income mothers: women who were applying for welfare benefits at a Department of Human Service (DHS) welfare office and women currently participating in a mandated welfare-to-work job training program (JTP). Possible selves were generated in response to an open-ended measure and then content-coded. First, we present data on the frequency of various possible selves that respondents listed, separating expected possible selves from feared possible selves and examining the strategies women describe as being linked to working on attaining possible selves or avoiding becoming like their feared possible selves. We test the hypothesis that women in the job training setting are less focused on educational goals than those applying for welfare benefits because women in job training are pressed to focus on breadwinning, while those who are still eligible for benefits can focus on education, perhaps as a means of becoming economically self-sufficient at a later time.

Participants were 313 mothers who were on average thirty-one years old (range: eighteen to fifty-nine years). About half of women $(n=171)$ were recruited from Michigan JTPs and the other half $(n=142)$ from DHS welfare office waiting rooms. Women were participating in job training programs to meet welfare-to-work requirements but were located separately from the welfare office. DHS participants were applying for benefits or visiting a caseworker. All of the women had at least one child living at home, and most (64 percent) were caring for children under the age of five. About four in ten participants were working at least part time (4l percent of DHS mothers and 42 percent of job training mothers). About half of the women (51.2 percent) were African American, others were mostly European American (40.6 percent), and the remaining 8.25 percent of mothers of another ethnic background. Though four in ten ( 40 percent) of mothers reported some education beyond high school, most had no education beyond that: 22 percent had not finished high school, 17 percent had a GED, and 21 percent had a high school diploma.

To assess possible selves, mothers were asked to describe their possible selves for the coming year with open-ended questions ("Next year, I expect to be ..." and "Next year I want to avoid being ..."). They were also asked what strategies, if any, they were using to reach their possible selves. Responses were content-coded as to whether they focused on the categories that follow, with illustrative examples for each category provided:

- Jobs—for example: getting a full-time job, working for myself, getting a stable job

- Material concerns_-for example: having a car, moving into a better apartment, buying clothes for children 
- Education-for example: going to school to be a nurse's assistant, getting job training

- Caregiving-for example: helping at my child's school more, making sure children stay out of trouble, worrying about family members

- Mental health-for example: not being depressed, being happy, trying to maintain a positive outlook

- Physical health-for example: expecting to lose weight, fearing substance abuse, or staying off drugs

Job and material concerns were most prevalent, with 73 percent of the respondents mentioning at least one job-expected possible self and 60 percent mentioning at least one expected-material-concern possible self. Yet education was highly salient: 39 percent of the respondents generated at least one expected education-related possible self, and 29 percent reported at least one strategy to attain that educational possible self. Because the focus of this chapter is education, results related to other domains are discussed in more detail elsewhere (Lee and Oyserman, 2006).

Employment (35 percent) and material concerns (43 percent) were also the most prevalent feared possible selves. In all domains, respondents reported far fewer feared possible selves than expected possible selves. Although all respondents generated at least one expected possible self, 91 percent generated at least one feared possible self. Respondents averaged 2.90 expected possible selves and 2.29 feared possible selves. Feared educational possible selves followed this pattern, with only 9 percent of respondents indicating that there were any education-related fears that they wished to avoid in the next year.

Descriptive Content of Expected Possible Selves. Content analysis of possible selves revealed the major concerns of the low-income mothers in this study. When educational goals were mentioned as an expected possible self, they were often broad and frequently included a general expectation such as obtaining a GED or going back to college.

However, many respondents explicitly linked education with their employment possible selves. Education was seen as a way to attain a career and find more satisfying employment, for example, linking the expectation of "being a manager" with the strategy of "learning and going to school." Education was even more common as a strategy to attain specific employment goals, such as working in day care, medical billing, or accounting, or being an emergency medical technician, mortgage broker, or home health care aide. For example, the expected possible self of being a day care provider was connected to the strategy of "becoming certified," or "working as an EMT" paired with the strategy of "finishing my course work." In sum, women's employment goals were seen through the lens of education, and pursuing education was second only to "going out there to apply for jobs" as a strategy for attaining better employment. 
Although few respondents were in school, those who were generated expected possible selves such as getting better grades, working on taking a proficiency exam, or waiting for the results of an exam. For those expecting to return to school, obtaining financial resources for education was the most commonly mentioned strategy to attain education-related possible selves. For example, the possible self of expecting to return to school was paired with strategies such as applying for financial aid, trying to get other sources of funding, paying off debts, waiting for transcripts to arrive from out of state, and getting registered for classes.

Importantly, education was connected to women's caregiving roles. A number of the mothers wrote about education in terms of their expectations for their children's educational futures. Emblematic of this were expected possible selves of "my child finishing high school," "my kids to be in the best school," or "sending my kids to college." Though not explicitly related to their personal educational expectations, education was seen as a way to care for children-for example, by expecting to be "volunteering more at my son's school" or "being involved more in my son's school activities."

Content of Feared Possible Selves. Overall, women generated fewer feared possible selves. Perhaps because relatively few were currently in school, education-related feared possible selves were uncommon. However, for those who were in school, responses included wanting to avoid "failing school" paired with the strategy of "working hard to stay on top of my grades," or wanting to avoid being "a failure in school" paired with the strategy of "getting things done early." Noteworthy is that at least one respondent who indicated wanting to avoid being on welfare in the next year linked that possible self with the specific strategy of "going to college."

Regression Analyses. Regression analyses were conducted to examine if individuals in the job training sites and welfare offices differed in the extent to which they were focused on education possible selves, with the hypothesis that being under immediate pressure to find employment (such as for women in the job training site) would be negatively related to frequency of education-related possible selves. (Negative binomial regression was used because the possible selves in the education domain were measured as a count score-total number of education-related possible selves mentioned-and data were skewed toward zero. Negative binomial regression is a maximum-likelihood Poisson model that is appropriate when the independent variable consists of nonnegative integer count of relatively uncommon events, such as criminal offenses; Osgood, 2000.)

Regression analyses indicated that there were no significant differences among women in the frequency of education-related possible selves. After controlling for education, race, current employment, and the number of children currently living at home, women in the job training programs and those applying for welfare were equally likely to have expected $(\beta=-.26$, $p=.24)$, feared $(\beta=-.13, p=.79)$, and developed strategies $(\beta=-.17$, $p=.46)$ related to their education possible selves. 


\section{Emerging Themes}

There are a number of reasons that it is important to examine the possible selves of adult women. As Frazier and Hooker (2006) noted, possible selves are a theoretical construct that can provide a blueprint for understanding unique aspects of self-development and the evolution of self-concept in adulthood. Possible selves serve as one way to understand the structure of one's current and future self (Cross and Markus, 1991; Leonardi, Syngollitou, and Kiosseoglou, 1998; Markus and Nurius, 1986). We extend the theory of possible selves to investigate the educational expectations of low-income mothers. Using possible selves theory will help educators and policymakers facilitate the transition from welfare to work by providing a fuller understanding of effective strategies to surmount the barriers that lowincome mothers face in attaining their goals.

Content analysis and regression results indicated that employment and material concerns were a pressing reality for the low-income mothers in this study. Although research indicates that women in job training sites are more focused on employment than their counterparts applying for welfare benefits (Lee and Oyserman, 2006), respondents in this study did not differ in terms of their focus on education. A surprisingly large percentage (38 percent) of the respondents mentioned at least one expected possible self related to education. All of the respondents were mothers, and nearly half of the respondents were also currently working, yet higher education was a highly salient future self for the respondents and was also mentioned as an aspiration for their children. However, pursuit of education in itself was not the end goal for most of these women. Only a small number mentioned the desire to gain knowledge simply for the sake of learning or personal growth. Most responses suggested that the women in this study see education as a means to achieve a better way of life by improving their employment options. The notion that education is a way off welfare and out of poverty is recurrent in women's educational possible selves (Lee and Oyserman, 2006; Oyserman and Fryberg, 2006).

Although many respondents have expected possible selves focused on education, few had feared educational possible selves. These results parallel several other studies indicating that feared possible selves are less salient (Leondari, Syngollitou, and Kiosseoglou, 1998; Robinson and Davis, 2003; Yowell, 2002). Yowell's study of Hispanic adolescent youth (2002) indicated that while many youth viewed education as a highly salient expectation for the future, fewer had feared possible selves or educational possible selves. Similarly, two studies of low-income women indicate that respondents had fewer feared than expected occupational possible selves (Lee and Oyserman, 2006; Robinson and Davis, 2003).

This dearth of feared possible selves means that women are less likely to have balanced education-focused possible selves. While focusing on the positive may seem like a good strategy, visualizing only positive outcomes 
without visualizing possible failure and strategizing how to get around it is not likely to be sufficient to sustain the motivation of low-income mothers to attain education-focused possible selves in the face of the real obstacles to time, energy, and resources they face. Balance may be especially important in a low-income context where obstacles and barriers to attaining possible selves are likely to present themselves, thus necessitating the need to anticipate and plan for setbacks. Indeed, targeting balance in possible selves and increasing the feasibility of possible selves strategies is one of the key reasons that past interventions have been successful in improving the academic and mental health outcomes of low-income minority youth (Oyserman and others, 2004; Oyserman, Johnson, and Bybee, 2005; Oyserman, Terry, and Bybee, 2002). Thus, lack of feared education possible selves may be a risk factor indicating that low-income mothers in the transition from welfare to work do not have the self-regulatory focus that would promote attainment of educational goals.

\section{Implications for Intervention}

It is difficult to turn possible selves into reality. Although women's educational possible selves clearly represent important and self-relevant goals, low-income mothers face a number of barriers, such as lack of adequate child care and transportation, that present challenges to educational pursuits (Danziger, Ananat, and Browning, 2004; Danziger and others, 2000). Furthermore, education is inconsistent with the welfare reform policy workfirst model that is focused on reducing the welfare roles by attaching women to the labor market as quickly as possible. Thus, intervention to help women attain their employment and educational possible selves is warranted at multiple points.

First, there is a need for welfare reform policies to support the educational goals of low-income mothers. Although the work-first model of quick attachment to the labor market may be beneficial in terms of reducing welfare caseloads in the short term, job retention is hindered by lack of adequate training and poor attitudes about working (Holzer and Wissoker, 2001). Educational attainment may be an effective long-term job training tool within the welfare system. Such activities could augment existing workfirst activities, for example, by promoting vocational training specific to the sorts of jobs women would like to attain (for example, vocational training focused on common job goals such as emergency medical technician, nurse practitioner, or day care licensure). Related to this, an additional policy change is to expand the list of education-related activities that count toward welfare-to-work requirements (Holzer and Wissoker, 2001).

Second, there is a need for individual-level interventions that link educational possible selves with activities to be enacted in the present. Using the example of education-related possible selves, one must first develop and 
then be able (Leondari, Syngollitou, and Kiosseoglou, 1998) to access those educational possible selves. Intervention should then focus on articulation of both expected (such as expecting to attain a GED) and feared possible selves (such as wishing to avoid not being considered for a job because of lack of a high school degree). A next step is to develop a concrete plan that links self-relevant expected and feared possible selves to behaviors in the present. Focus on facilitating women's personal employment goals may also promote better attitudes about work (Holzer and Wissoker, 2001). In the case of a low-income mother on welfare, developing a plan to sign up for GED classes or buying a study guide for the GED are present-oriented behaviors that can facilitate the possible self of attaining a GED.

A key component of possible selves intervention is promoting articulation of feasible strategies to attain possible selves. Strategies should be specific and attainable, and directly target barriers that research indicates women will encounter in the process of attaining education. These strategies may build on past successful experiences with employment and education, or use the experiences of close others who have been successful. For example, a positive role model such as a mother or sibling who has attained higher education may make goals seem more attainable (Kerpelman, Shoffner, and Ross-Griffin, 2002; Robinson and Davis, 2003).

\section{Conclusion}

In this study, we expanded current knowledge related to the possible selves of low-income mothers. We documented the high frequency of educationrelated possible selves and showed that mothers in job training site and other welfare settings are equally likely to have education-related possible selves. Welfare programs and policies would better serve women's long-term job interests if they addressed the educational possible selves of low-income mothers. This could be accomplished through innovative interventions that integrate policy-level initiatives supporting women's educational goals and individual-level intervention targeting articulation of feared educational possible selves and specific strategies intended to facilitate attainment of possible selves.

\section{References}

Boesel, D., Alsalam, N., and Smith, T. M. Educational and Labor Market Performance of GED Recipients. Washington, D.C.: U.S. Department of Education, 1998.

Cross, S., and Markus, H. "Possible Selves Across the Lifespan." Human Development, 1991, 34, 230-255.

Danziger, S., and Johnson, R. C. "Welfare Reform: The Morning After." Milken Institute Review, 2005, 1, 9-15.

Danziger, S. K., Ananat, E. O., and Browning, K. G. "Childcare Subsidies and the Transition from Welfare to Work." Family Relations, 2004, 53, 219-228. 
Danziger, S. K., and others. "Barriers to Employment of Welfare Recipients." In R. Cherry and W. M. Rodgers III (eds.), Prosperity for All? The Economic Boom and African Americans. New York: Russell Sage Foundation, 2000.

Dunkel, C. S., and Anthis, K. S. "The Role of Possible Selves in Identity Formation: A Short-Term Longitudinal Study." Journal of Adolescence, 2001, 24, 765-776.

Frazier, L. D., and Hooker, K. "Possible Selves in Adult Development: Linking Theory and Research." In C. Dunkel and J. Kerpelman (eds.), Possible Selves: Theory, Research and Applications. Happauge, N.Y.: Nova Science, 2006.

Holzer, H. J., and Wissoker, D. How Can We Encourage Job Retention and Advancement for Welfare Recipients? Washington, D.C.: Urban Institute, 2001.

Hooker, K., and others. "Possible Selves Among Parents of Infants and Preschoolers." Developmental Psychology, 1996, 32, 542-550.

Kerpelman, J. L., Shoffner, M. F., and Ross-Griffin, S. "African American Mothers' and Daughters' Beliefs About Possible Selves and Their Strategies for Reaching the Adolescents' Future Academic and Career Goals." Journal of Youth and Adolescence, 2002, 31, 289-302.

Kim, K., Hagedorn, M., Williamson, J., and Chapman, C. Participation in Adult Education and Lifelong Learning: 2000-01. Washington, D.C.: U.S. Department of Education, National Center for Education Statistics, 2004.

Lee, S. Women's Work Supports, Job Retention, and Job Mobility: Child Care and EmployerProvided Health Insurance Help Women Stay on Jobs. Washington, D.C.: Institute for Women's Policy Research, 2004.

Lee, S. J., and Oyserman, D. "Expecting to Work and Fearing Homelessness: The Possible Selves of Low-Income Women." Unpublished manuscript, 2006.

Leondari, A., Syngollitou, E., and Kiosseoglou, G. "Academic Achievement, Motivation and Possible Selves." Journal of Adolescence, 1998, 21, 219-222.

Loprest, P. How Families That Left Welfare Are Doing: A National Picture. Washington, D.C.: Urban Institute, 1999.

Loprest, P., and Zedlewski, S. The Changing Role of Welfare in the Lives of Low-Income Families with Children. Washington, D.C.: Urban Institute, 2006.

Markus, H. R., and Nurius, P. "Possible Selves." American Psychologist, 1986, 41, 954-969.

Osgood, D. W. "Poisson-Based Regression Analyses of Aggregate Crime Rates." Journal of Quantitative Criminology, 2000, 16(1), 21-43.

Oyserman, D. "Social Identity and Self-Regulation." In E. T. Higgins and A. Kruglanski (eds.), Social Psychology: Basic Principles. (2nd ed.) New York: Guilford Press, forthcoming.

Oyserman, D., Bybee, D., and Terry, K. "Possible Selves and Academic Outcomes: How and When Possible Selves Impel Action." Journal of Personality and Social Psychology, 2006, 91, 188-204.

Oyserman, D., Bybee, D., Terry, K., and Hart-Johnson, T. "Possible Selves as Roadmaps." Journal of Research in Personality, 2004, 38, 130-149.

Oyserman, D., and Fryberg, S. "The Possible Selves of Diverse Adolescents: Content and Function Across Gender, Race and National Origin." In C. Dunkel and J. Kerpelman (eds.), Possible Selves: Theory, Research, and Application. Happauge, N.Y.: Nova Science, 2006.

Oyserman, D., Johnson, E., and Bybee, D. Possible Selves in Early Adolescence: Content and Contextual Predictors. Ann Arbor: University of Michigan, 2005.

Oyserman, D., and Markus, H. "Possible Selves in Balance: Implications for Delinquency." Journal of Social Issues, 1990, 46, 141-157.

Oyserman, D., Terry, K., and Bybee, D. "A Possible Selves Intervention to Enhance School Involvement." Journal of Adolescence, 2002, 25, 313-326.

Robinson, B. S., and Davis, K. L. "Motivational Attributes of Occupational Possible Selves for Low-Income Rural Women." Journal of Counseling Psychology, 2003, 50, 156-164. 
U.S. Bureau of the Census. Women in the Labor Force: A Databook. Washington, D.C.: U.S. Department of Labor, 2005.

Yowell, C. M. "Dreams of the Future: The Pursuit of Education and Career Possible Selves Among Ninth Grade Latino Youth.” Applied Developmental Science, 2002, 6(2), 62-72.

SHAWNA J. LEE is assistant professor in the School of Social Work at Wayne State University in Detroit, Michigan, and holds a joint appointment with the Merrill-Palmer Skillman Institute for Child and Family Development.

DAPHNA OYSERMAN is professor in the Department of Psychology and School of Social Work and research professor at the Institute for Social Research, University of Michigan, Ann Arbor. 